\title{
Impact of ERPS on Organizations' Financial Performance
}

\author{
Ali SERHAN \\ The Bucharest University of Economic Studies, Bucharest, Romania \\ e-mail: serhanali333@gmail.com \\ Wissam EL HAJJ \\ The Bucharest University of Economic Studies, Bucharest, Romania \\ e-mail:whajj@damana.com
}

PICBE | 361

\begin{abstract}
In accounting, enterprise resource planning system is the database software package for supporting all corporations' operations and processes such as marketing, human resources, finance, manufacturing, and several others. ERPS stores different forms of data for various computerized functions in a single database, user interface, and application. Although ERPS were initially utilized by huge manufacturing corporations, they are currently used by all sizes of businesses. Therefore, there is a need to identify the performance advantages that businesses gain from ERPS together with its impact on the performance of a firm. The goal of the research is to offer insights regarding the implementation of ERPS and their influence on organizational performance. The study will determine the benefits of ERPS, identify if there is a reliable or valid performance measurement system that connects ERPS to the performance of the organization, identify if ERPS have a positive effect on the performance of a company in the time periods after implementation and finally set the success factors accountable for the ERPS benefits. Accordingly, the study will establish the effect of ERPS on the performance of a company. The study will be a quantitative research where questionnaires will be used to collect the primary data. Purposive sampling will be used to obtain 50 answers from accounting experts so that to evaluate the effect of ERPS on financial performance and auditing of Lebanese firms. Moreover, financial performance indicators will be used to assess the overall company performance together with supplychain operations. Quantitative analysis of data will be done through the use of SPSS based on the research objectives.
\end{abstract}

Keywords: ERP, financial performance, accounting and finance, competitiveness, management efficacy.

\section{Introduction}

\section{Background information}

ERP (enterprise resource planning), refers the technological world used to explain the management software that entails modules such as marketing, human resources, finance and production and that permits firms to plan their services and goods (Aburub, 2015). Moreover, ERP incorporates external and internal management data across the whole company, embracing accounting, sales, manufacturing, customer relationship, and service management. It is worth noting that lack of alignment between investments in Information Technology (IT) and business strategy is a major reason why most companies fail to realize fully the benefits of large scale systems like ERP system (summer, 2009).

The major rationale of ERP is to facilitate the flow of information between all functions of a business inside the boundaries of the firm and manage the links to the outside stakeholders (Aldossari \& Mukhtar, 2018). Similar to other businesses in the world, firms in Lebanon conduct various internal and external activities that have led to the use of ERP. Due 
to the advanced technology and competition in the global market, ERP has been widely used to promote the performance of an organization (Trott\& Hoecht, 2013).

\section{Problem statement}

In recent days, ERP systems have become broadly utilized in almost all sectors of a company thus making the software useful in the contemporary world. A successful enterprise centers on an aggressive and efficient utilization of information technology thus making ERP the core of successful information management and backbone of several organizations (Altamony, AlSalti, Gharaibeh, \& Elyas, 2016). The ERP system is built on the promise that critical data will be integrated into a single database. Several companies face the challenge of consolidating information from different departments although the issue has been addressed by the use of ERP. Many studies have been carried out on the challenges of implementing ERP. However, significantly fewer researches have been done on the benefits and impact of ERP on the performance of an organization. The major reason for the reduced number of studies on the theme is because it takes up to five years before the effect of EPR is recognized. In Lebanon, little has been done on the ERP system utilization and its impact on firm performance (Almajali, Masa'deh, \& Tarhini, 2016). Therefore, the study sought to find out the impact of ERP on the performance of companies in Lebanon.

\section{Objectives}

The goal of the research is to offer insights regarding the adoption of ERP and their effect on organizational performance. The specific objectives of the study are:

I. To establish if ERP systems have an effect on the financial performance of companies in Lebanon.

II. To evaluate the impact of organizational factors on the success of EPR.

III. To determine if the performance measurement systems connect ERP to the performance of the organization.

IV. To recognize the benefits of ERP.

\section{Research question}

The major study questions include:

1. What are the benefits of using ERP?

2. Is there a reliable or valid performance measurement system that connects ERP to the performance of the organization?

3. Do ERP system have a positive effect on the performance of a company in the time periods after implementation?

4. What are success factors accountable for the ERP benefits?

By investigating the above questions, the study will establish the effect of ERP systems on the performance of a company.

\section{Study hypothesis}

$\mathrm{H}_{1}$ : ERP has significant impact on the financial performance of Lebanese companies.

$\mathrm{H}_{2}$ : The use of ERP is positively associated to the overall organizational performance. 


\section{Conceptual framework}

The conceptual framework shows the relationship between variables that affect financial performance of companies in Lebanon. It is presumed that when companies implement the various ERP modules, such as transactional applications, advanced applications and management decision support application then they will have an improved financial performance due to the timely generation of financial statements and reports. Three aspects of business; Return on equity, margin of profit and return on assets are likely to show an improvement. However, this may be greatly affected by organizational factors during preimplementation and post implementation. Management style, production targets, firms' ownership and years of operation are likely to affect the relationship between ERP systems and financial performance of companies in Lebanon.

\section{Literature review ERP system}

According to Altamony et al. (2016), ERP is the system that has assisted companies to exploit better their business data. The systems are distinguished from the past generation of data systems because they allow businesses to integrate enterprise processes and optimize the resources. Furthermore, ERP systems are regarded as a single application, database and unified interface in the whole organization (Altamony et al., 2016). As a result, they provide unique advantages to the companies that implement them by improving the process of decision making via the provision of timely and appropriate information. In the modern world, globalization has necessitated most of the firms to standardize their activities and establish best practices offered by ERP which has ensured quality and predictability in the worldwide business interests by decreasing the duration cycle from purchase to delivery (Ha \& Ahn, 2014).

The ERP usage and integration is an exceptionally mind boggling procedure and expansive frameworks are utilized to their authoritative structure for change. Jarvinen (1991) found the IS field is extremely expansive, with various diverse definitions relying upon the analyst's perspective and an ERP framework is considered as that immense data framework that coordinates all the data that goes through the association into a uniform framework. Moreover, the material pertinent to IS systems and techniques and its subsequent results has likewise been looked into and the best approach chosen dependent on the coveted result of this exploration ponder. Innovation assumes a key job in the present business condition. Several businesses relay on PCs and programming to generate precise data which facilitate a running of their organizations.

Connell (2009) says that, communication is the ability to transmit information in a way that the intent of it is received appropriately. To progress and accomplish a transaction communication is important when negotiating during sales, when deliveries are being made and in all aspects. It brings together the elements within a firm's environmental set ensuring objective achievements with the growth of technology. It has been made easy to perform function since improved skills have been identified. In order to manage strategy implementation, it is very important for organizations to have proper communication which facilitates proper management of strategy. They are supposed to be included in the strategic planning committee and given a chance to contribute to design of the strategy and how it should be implemented (Forman \& Argenti, 2009). 
The figure above illustrates the core components of the ERP software which comprises of e-business, accounting, human resource, production, business intelligence, supply chain, and customer relationship. The software is a useful tool that an organization can utilize to establish a sound and robust data system infrastructure as well as enabling the administration to make better choices (Ince, Imamoglu, Keskin, Akgun, \& Efe, 2013).

According to Koch (2011), some of the drivers to adopting an ERP system majorly depended upon the work experience, appropriate executive sponsorship and commitment to the initiatives outlined in the objectives of the firm. He however observed that the presence of past IT projects does not necessarily influence or drive the willingness to adopt the system. Koch (2011) in his research stated that ERP systems are expensive, huge and complex systems that warrant careful planning and execution for successful adoption. He associated ERP system with Rogers's theory of diffusion of innovations. However, there is a knowledge gap in adoption of ERP'S and organizational performance especially in Lebanese companies (Gattiker \& Goodhue (2005).

Companies may have many reasons for integration ERP based on the size and industry. The common rationale of implementing ERP is to standardize systems and process. According to Koch (2011), enterprise resource planning does produce successful and reliable decision due to the provision of real time data in a format of a report that enables organizations to enhance specific management procedures and functions. Enterprise resource planning implementation has brought lots of benefits to organizations such as reduction of procurement charges, lowering administration rates, coming up with highly successful sale policies and reducing indirect and direct labour expenditures (Legare, 2002).

\section{Performance measurement}

Firm performance is an important construct of a management research and entails three areas of the company including product market, shareholder return, and financial performance. For the past decade, businesses have renewed their interest in assessing organization programs and their effect (Ince et al., 2013). Performance measurement is the selection and utilization of qualitative and quantitative measures of project or program capacities, outcomes and processes to inform the public or an agency regarding critical features of the project. The implementation of new administrative practices over the past years has led to the measurement of performance with regards to the suitability of the performance measurement systems. The common performance measurement is founded on the input, outcome, process and output measures (Rothenberger, Srite, \& Jones-Graham, 2010).

\section{Methodology \\ Research design}

The study design of the study was descriptive quantitative research because it permits the manipulation of a variable at a time while filtering external factors (Shen, Chen, \& Wang, 2016). The study manipulated the dependent variable (performance of the company) against the independent variable of ERP systems in Lebanon. This concurs with Mugenda and Mugenda (2003), when they said that the descriptive approach can be used when the problem is specific and the researcher has an emphasis of determination of how the problem is influenced by the different variables under study. 


\section{Sampling}

In this research, the sampling frame was guided by the position individual respondents held in the organization. The target population was accounting experts of different companies in Lebanon which have implemented ERP. Purposive sampling was used to obtain 50 accounting experts as respondents so that to evaluate the effect of ERP financial performance and auditing. According to purposive sampling, the sample was selected since they fulfil particular criteria with which the study is concerned with (Matolcsy, Booth, \& Wieder, 2005).

PICBE | 365

\section{Data collection instrument}

According to Mugenda (2003) data collection instruments refer to tools used in data collection while conducting a study. This study relied on questionnaire in collection of data. The questionnaire method was preferred because it is economical compared to other methods available. The data collection instruments were self-administered, open-ended and structured questionnaires since they are economical.

\section{Data collection procedure}

The research took an introduction letter from the university. After this, the researcher booked an appointment with the various directors to request for permission to collect data. The researcher then visited various respondents' offices to administer the questionnaires himself. The data collection procedure entailed both secondary and primary data. The primary data was collected from participants while secondary information will be obtained from documents such as website, industry report and I.S publications. Before, carrying out the study, the pilot study was done to test the validity and reliability of the instruments. Random sampling was used to select 10 companies that was not studied on the main research. Any errors or issue identified from the questionnaires were edited.

\section{Data analysis}

Data analysis (also referred as data processing) is the process of examining every component of data provided through critical analysis and logical reasoning. In a study, the data is collected, reviewed and analyzed so that the researcher can come up with a valid interpretation and conclusion Mugenda and Mugenda (2003). The data collected was analyzed using the statistical package for social sciences software.

\section{Results and discussions}

Reliability test

This is a test to determine the extent to which assessment tools used in the study produces a stable and consistent result. If Cronbach's alpha is greater than 0.7 the findings are concluded to be reliable.

Table 1: statistics of reliability in the study

\begin{tabular}{|r|r|}
\hline Cronbach's Alpha & \multicolumn{2}{|c|}{$\begin{array}{c}\text { Number of } \\
\text { Items }\end{array}$} \\
\hline 0.973 & 28 \\
\hline
\end{tabular}

Source: from the research of author The Cronchbach's alpha in this study scored greater than 0.7 therefore the findings are reliable. 


\section{Correlation test}

Apparently big part of the sample does not apply ERPS, hence there is a gap in this new trend. The following regression test, assess the correlation with the variables that affect the correlation with the implementation of ERPs.

\begin{tabular}{|c|c|c|c|c|c|c|c|c|}
\hline \multicolumn{9}{|c|}{ Correlations } \\
\hline & & Department & Position & Education & Gender & Age & Experience & $\begin{array}{c}\text { The ERP } \\
\text { system you } \\
\text { have in your } \\
\text { organization }\end{array}$ \\
\hline \multirow[t]{3}{*}{ Position } & $\begin{array}{l}\text { Pearson } \\
\text { Correlation }\end{array}$ & $-.770^{* *}$ & & & & & & \\
\hline & $\begin{array}{l}\text { Sig. (2- } \\
\text { tailed) }\end{array}$ & .000 & & & & & & \\
\hline & $\mathrm{N}$ & 50 & & & & & & \\
\hline \multirow[t]{3}{*}{ Education } & $\begin{array}{l}\text { Pearson } \\
\text { Correlation }\end{array}$ & $-.514^{* *}$ & $.399^{* *}$ & & & & & \\
\hline & $\begin{array}{l}\text { Sig. (2- } \\
\text { tailed) }\end{array}$ & .000 & .004 & & & & & \\
\hline & $\mathrm{N}$ & 50 & 50 & & & & & \\
\hline \multirow[t]{3}{*}{ Gender } & $\begin{array}{l}\text { Pearson } \\
\text { Correlation }\end{array}$ & $.692^{* *}$ & $-.517^{* *}$ & $-.491^{* *}$ & & & & \\
\hline & $\begin{array}{l}\text { Sig. (2- } \\
\text { tailed) }\end{array}$ & .000 & .000 & .000 & & & & \\
\hline & $\mathrm{N}$ & 50 & 50 & 50 & & & & \\
\hline \multirow[t]{3}{*}{ Age } & $\begin{array}{l}\text { Pearson } \\
\text { Correlation }\end{array}$ & .202 & $-.658^{* *}$ & .242 & -.016 & & & \\
\hline & $\begin{array}{l}\text { Sig. (2- } \\
\text { tailed) }\end{array}$ & .159 & .000 & .091 & .911 & & & \\
\hline & $\mathrm{N}$ & 50 & 50 & 50 & 50 & & & \\
\hline \multirow[t]{3}{*}{ Experience } & $\begin{array}{l}\text { Pearson } \\
\text { Correlation }\end{array}$ & .271 & $-.460^{* *}$ & $-.314^{*}$ & -.005 & .005 & & \\
\hline & $\begin{array}{l}\text { Sig. (2- } \\
\text { tailed) }\end{array}$ & .057 & .001 & .026 & .973 & .973 & & \\
\hline & $\mathrm{N}$ & 50 & 50 & 50 & 50 & 50 & & \\
\hline \multirow{3}{*}{$\begin{array}{l}\text { Which ERP } \\
\text { (enterprise } \\
\text { resource } \\
\text { planning) } \\
\text { system do } \\
\text { you have }\end{array}$} & $\begin{array}{l}\text { Pearson } \\
\text { Correlation }\end{array}$ & $.349^{*}$ & $-.327^{*}$ & $-.568^{* *}$ & $.303^{*}$ & -.022 & $.338^{*}$ & \\
\hline & $\begin{array}{l}\text { Sig. (2- } \\
\text { tailed) }\end{array}$ & .013 & .021 & .000 & .033 & .877 & .016 & \\
\hline & $\mathrm{N}$ & 50 & 50 & 50 & 50 & 50 & 50 & \\
\hline
\end{tabular}




\section{Discussion}

From the above graphical and tabulated results, the study findings can be deduced. Firstly, the reliability test through Cronbach's alpha test confirms that the results obtained from the questionnaires were highly reliable. For further findings, the frequency test was used to analyze the obtained data from diverse perspective, including demographic and assessment data from the study participants. Participants were categorized and assessed depending on their levels of professional expertise, departmental positions, age, gender, and educational levels. Majority of study participants were from operations department and position. Regarding the education level, the largest number of respondents was diploma holders, followed by certificate and finally the undergraduate degree holders. Gender composition was a bit imbalanced, with males being the majority. The majority age bracket was that of between 26 and 30 years, while with regards to experience, most of the respondents were employees with less than 5 years in their respective companies.

Results from this diverse group of participants indicated that majority of companies in Lebanon currently embrace the use of enterprise resource planning systems (ERPS). This is an indication that, over time, the use of ERPs has proved to have significant influence on the performance of firms that employ it. Despite the fact that many respondents confirmed low level of knowledge of ERPs in their companies, those who had knowledge about the system praised it for extraordinary improvement of organizational performance. In Lebanon, a good number of companies have failed to adopt the newly emerging technological systems, which are meant to make the management and operational roles easier. For instance, many participants indicated that their companies do dot value the IT department of their organizations. Since that was the case, a good number also confirmed that they had no idea whether the ERP system helped their organization attain its goals or not. This is the reason for the high values in the tables and graphs indicating 'neither agree nor disagree.' The participants were quite unsure whether the data used in their armature ERP systems are accurate, reliable, easy to use, efficient, easy to learn, flexible or not. As such, the ERP system effects on user requirements, IT integration, firm sales revenue generation, new customer acquisition, market share, and customer retention still remain questionable among the Lebanese firms. The lack of surety from the study respondents is evident through the dominant answers of 'neither agree nor disagree.' In that context, the study results indicate that many respondents were not certain whether the ERP systems would help improve the business performance of their firms or not.

From the correlation test, the results reveal that a good number of the sampled participants worked in companies that did not utilize the ERPS. Consequently, the study depicts a gap in this new technological trend. Nevertheless, of the few participants whose firms implemented the system, the regression test used to assess the correlation between study variables indicated a significant relationship between ERPS implementation and company performance. This confirms the study hypothesis that ERP has significant influence on the financial performance of companies. Therefore, the use of ERPS can positively be linked to the overall organizational performance.

\section{Conclusion}

With the emergence of new technological approaches toward the management of organizational operations, companies continue to embrace the new technologies in order to 
attain their competitive advantage. On of such technologies is the enterprise resource planning system (ERPS), which is a software database useful for coordinating and monitoring operations. The key areas for such operations may include the human resources, finance, marketing and promotion, and manufacturing among several others. Through the ERP system, data can easily be collected, analyzed, sored, monitored, and used for enhancing different organizational operation. In order to assess the effectiveness of this new technology in improving the Lebanese organizational performance, the study employed quantitative methods. 50 study respondents, who were majorly company professionals at the accounting, auditing, and operational departments, were randomly sampled and questionnaires distributed to them. The data obtained from these respondents was then analyzed quantitatively using SPSS and findings deduced from obtained results, while closely focusing on the study objectives.

From the findings, it can be stated that majority of companies in Lebanon have not implemented the use of ERP system. The study findings reveal a technological gap, which points at the reluctance of companies to embrace the use of ERP. Consequently, many respondents were unsure whether the implementation of this system would be beneficial to their companies or not. They are not sure of the effectiveness or benefits brought by this technology to their organizational performance. However, the few respondents whose companies had implemented the ERP system confirmed having seen great benefits in it. They associated their companies' use of ERP systems to the possible improvements in financial and operational performance.

Nevertheless, the study findings revealed a technological gap that future studies need to explore. Majority of the respondents were not sure whether the organizations valued IT systems or not. They possibly believe that the ERP technology does not have any positive influence of their company performance. The major study limitation was that many participants were meeting the term ERPS for the first time. This shows that the idea of ERP system implementation is something that has not widely spread in the Lebanese corporate market. Therefore, future researchers should be able to focus on the level of awareness of the Lebanese public and organization leaders on the use of ERP and its benefits on operational performance. Moreover, further studies should also be conducted to explore the financial benefits of this newly emerging technology.

\section{References}

Aburub, F. (2015). Impact of ERP systems usage on organizational agility: An empirical investigation in the banking sector. Information Technology \& People, 28(3), 570-588.

Aldossari, S., \& Mukhtar, U. A. (2018). Enterprise Resource Planning and Business Intelligence to Enhance Organizational Performance in Private Sector of KSA: A Preliminary Review. In International Conference of Reliable Information and Communication Technology (pp. 343-352). Springer.

Almajali, D. A., Masa'deh, R., \& Tarhini, A. (2016). Antecedents of ERP systems implementation success: a study on Jordanian healthcare sector. Journal of Enterprise Information Management, 29(4), 549-565.

Altamony, H., Al-Salti, Z., Gharaibeh, A., \& Elyas, T. (2016). The relationship between change management strategy and successful enterprise resource planning (ERP) 
implementations: A theoretical perspective. International Journal of Business Management and Economic Research, 7(4), 690-703.

Connell, G. (2009). Organizational training, 3rd edition, prentice hall publishers, New Delhi, India.

Forman, J., \& Argenti, P. (2009). How Corporate Communication Influences ERP implementation, Reputation and Corporate Brand, Corporate Reputation Review, $8,245-264$.

Gattiker, T. \& Goodhue, D. (2005). What Happens After ERP Implementation: Understanding the Impact of interdependence and differentiation of Plant-Level outcomes, MIS Quarterly, 29(3), 559-585.

Ha, Y. M., \& Ahn, H. J. (2014). Factors affecting the performance of Enterprise Resource Planning (ERP) systems in the post-implementation stage. Behaviour \& Information Technology, 33(10), 1065-1081.

Ince, H., Imamoglu, S. Z., Keskin, H., Akgun, A., \& Efe, M. N. (2013). The impact of ERP systems and supply chain management practices on firm performance: case of Turkish companies. Procedia-Social and Behavioral Sciences, 99, 1124-1133.

Järvinen, P. (1991). 'On Approaches in Information Systems Research', in Proceedings of the 14th Information Systems Research In Scandinavia, Umeå, Sweden.

Koch, C. (2011). Enterprise Resource Planning: Information technology as a steamroller for management politics? Journal of Organizational Change Management, 14 (1), 64-78.

Legare, T., (2002) The Role of Organizational factors in realizing ERP benefits. Information Systems Management.

Matolcsy, Z. P. Booth, P. \& Wieder, B. (2005). Economic Benefits of Enterprise Resource Planning Systems: Some Empirical Evidence, Accounting \& Finance, 45, 439-456.

Mugenda, 0. \& Mugenda, A (2003). Research Methods, 3rd edition, Labis graphics Service, Nairobi, Kenya.

Rai, M. (2010). Benefits of ERP Software in India and Benefits of ERP Software in Africa. Global Press Release Journal, 3(1), 20-49.

Rothenberger, M. A., Srite, M., \& Jones-Graham, K. (2010). The impact of project team attributes on ERP system implementations: A positivist field investigation. Information Technology \& People, 23(1), 80-109.

Summer, M. (2009), Enterprise resource planning, Upper Saddle River, New Jersey, Prentice-Hall.

Shannak, R. O. (2015). The Impact of Implementing an Enterprise Resource Planning System on Organizational Performance Using Balanced Scorecard. Journal of Management Research, 8(1), 37-54.

Shen, Y.-C., Chen, P.-S., \& Wang, C.-H. (2016). A study of enterprise resource planning (ERP) system performance measurement using the quantitative balanced scorecard approach. Computers in Industry, 75, 127-139.

Trott, P. \& Hoecht, A. (2013). Enterprise resource planning and its impact on innovation. International Journal of Innovation Management, 8(4), 257-70.

Ulrich, Remus (2007). Critical success factors for implementing enterprise portals: A comparison with ERP implementations, Business Process Management Journal, 13(4), 538-552. 


\section{Appendix}

Questionnaire

\section{SECTION A: GENERAL INFORMATION}

1. Name of the Department

2. Position of the person filling the questionnaire

3. Please indicate your highest level of formal education

Certificate $\square$ Diploma $\square$ University first degree $\square$ Post graduate $\square$

4. What is your gender?

Female

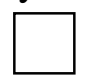

Male

5. Please indicate your age bracket

Below $25 \mathrm{yrs} \square$ 26-30yrs $\square$ 31-40 yr $\square$ Above $40 \mathrm{yrs}$

6. For how long have you worked in the department named above?

Less than 5 years $\square$ 5-10 years $\square$ above 10 years

SECTION B: EFFECT OF ERP ON ORGANISATIONAL PERFORMANCE

7a). Your organization has a Headquarters (HQ) somewhere else that coordinates your activities: ( ) Yes ( ) No

b) Which ERP (enterprise resource planning) system do you have?:

examples: SAP, Oracle, JD Edwards, Navision, Scala, Baan, Nova, Movex, i2, Proteus, etc.

c) When (year) did your organization COMPLETE the implementation of the ERP system:

8. To what extent do you agree or disagree with the statements provided below. 1-strongly disagree, 2- disagree, 3- neutral, 4- agree and 5- strongly agree

\begin{tabular}{|l|l|l|l|l|}
\hline 1 & 2 & 3 & 4 & 5 \\
\hline $\begin{array}{l}\text { In our organization, } \\
\text { decision making is } \\
\text { kept ONLY at the top }\end{array}$ & & & & \\
\hline $\begin{array}{l}\text { In our organization, } \\
\text { rules and procedure } \\
\text { are clearly documented } \\
\text { and are known to all } \\
\text { employee }\end{array}$ & & & & \\
\hline & & & & \\
\hline
\end{tabular}


9. How valuable is the information technology (IT) department in your organization?:

( ) Not valued at all ( ) Moderately valued ( ) Valued ( ) Highly valued

10. To what extent do you agree or disagree with the statements provided below. (1-strongly disagree, 2- disagree, 3-neutral, 4- agree and 5- strongly agree)

\begin{tabular}{|l|l|l|l|l|l|}
\hline Statement & $\mathbf{1}$ & $\mathbf{2}$ & $\mathbf{3}$ & $\mathbf{4}$ \\
\hline $\begin{array}{l}\text { Our ERP system } \\
\text { supports our business } \\
\text { goals }\end{array}$ & & & & & \\
\hline $\begin{array}{l}\text { The management of } \\
\text { our firm freely share } \\
\text { information }\end{array}$ & & & & & \\
\hline $\begin{array}{l}\text { The different } \\
\text { departments are of } \\
\text { equal } \\
\text { importance to top } \\
\text { management }\end{array}$ & & & & & \\
\hline $\begin{array}{l}\text { Top management } \\
\text { supports the adoption } \\
\text { and use } \\
\text { of our ERP system }\end{array}$ & & & & & \\
\hline $\begin{array}{l}\text { Employees are happy } \\
\text { with the changes that } \\
\text { management decides } \\
\text { on ERP issues }\end{array}$ & & & & & \\
\hline
\end{tabular}

11.To what extent do you agree or disagree with the statements provided below. (1-strongly disagree, 2- disagree, 3- neutral, 4- agree and 5- strongly agree)

\begin{tabular}{|l|l|l|l|l|l|}
\hline Statement & $\mathbf{1}$ & $\mathbf{2}$ & $\mathbf{3}$ & $\mathbf{4}$ & $\mathbf{5}$ \\
\hline $\begin{array}{l}\text { Our ERP has accurate } \\
\text { data }\end{array}$ & & & & & \\
\hline Our ERP is flexible & & & & & \\
\hline $\begin{array}{l}\text { Our ERP is easy to } \\
\text { use }\end{array}$ & & & & & \\
\hline $\begin{array}{l}\text { Our ERP is easy to } \\
\text { learn }\end{array}$ & & & & & \\
\hline Our ERP is reliable & & & & & \\
\hline $\begin{array}{l}\text { Our ERP allows data } \\
\text { integration }\end{array}$ & & & & & \\
\hline Our ERP is efficient & & & & & \\
\hline $\begin{array}{l}\text { Our ERP allows for } \\
\text { customization }\end{array}$ & & & & & \\
\hline $\begin{array}{l}\text { Our ERP has good } \\
\text { features }\end{array}$ & & & & \\
\hline
\end{tabular}




\begin{tabular}{|l|l|l|l|l|l|}
\hline Our ERP allows for & & & & & \\
integration with other & & & & & \\
IT & & & & & \\
systems & & & & & \\
\hline $\begin{array}{l}\text { Our ERP meets userse } \\
\text { requirements }\end{array}$ & & & & \\
\hline
\end{tabular}

\section{SECTION C: ORGANISATIONAL PERFORMANCE}

12. The statements below are concerned with firm performance. Please tick the one that best describes your opinion. Use the following scale. 1- strongly disagree, 2- disagree, 3neutral, 4- agree and 5- strongly agree

\begin{tabular}{|l|l|l|l|l|l|}
\hline Statement & $\mathbf{1}$ & $\mathbf{2}$ & $\mathbf{3}$ & $\mathbf{4}$ & \\
\hline $\begin{array}{l}\text { Our firm has stronger } \\
\text { growth in sales } \\
\text { revenue. }\end{array}$ & & & & & \\
\hline $\begin{array}{l}\text { Our firm is better able } \\
\text { to acquire new } \\
\text { customers. }\end{array}$ & & & & & \\
\hline $\begin{array}{l}\text { Our firm has a greater } \\
\text { market share. }\end{array}$ & & & & & \\
\hline $\begin{array}{l}\text { Our firm is able to } \\
\text { increase sales to } \\
\text { existing } \\
\text { customers }\end{array}$ & & & & & \\
\hline $\begin{array}{l}\text { ERP facilitates profit } \\
\text { maximisation and } \\
\text { eventually leads to } \\
\text { improved business } \\
\text { performance }\end{array}$ & & & & & \\
\hline $\begin{array}{l}\text { ERP improves } \\
\text { competitive advantage } \\
\text { and lowers } \\
\text { transaction costs }\end{array}$ & & & & & \\
\hline
\end{tabular}

